\title{
Obituaries
}

Obituaries should be submitted by email to Jonathan Coe at jonathan.coe@nature.com.

All submitted obituaries should be 400 words maximum in length (apart from obituaries for past presidents of the BDA where the length should be 800 words).

Content of the obituary is down to the individual author, and the approval of the family should be given for the obituary prior to submission to the BDJ.

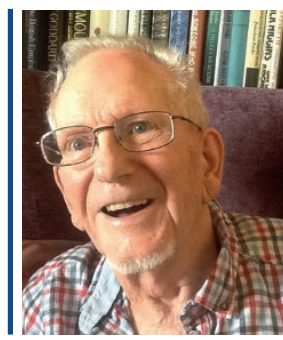

Tom Harman Smith

1933-2018

Tom Harman Smith was the epitome of the high street family dentist whose practice is a little bit of everything. He readily admitted that he enjoyed the management and administration of oral health more than its scientific base. Long before leadership became a discipline in its own right, Tom was fascinated by the consensus process and the way health professionals prioritise decisions. This applied both to his own practice and networking with peers. His most notable achievements were editing and producing the Barnet LDC Newsletter with a national circulation to other LDCs, managing the BDA's Middx \& Herts Branch and later becoming the British Dental Health Foundation(BDHF)'s secretary. Tom was also an incessant lobbyist for dentistry with the sometime MP for Finchley.

Tom was a fourth generation dentist. Born in Loughborough he went to Birmingham where he qualified in 1956. As a student he was involved in playing banjo in a New Orleans jazz group that toured. After qualifying he became an associate in a group practice in North Finchley where he immediately became an active member in both the BDA and the old Middlesex LDC. Tom crafted his journalistic skills in 1971 when he took his family to Ascension Island for a year where he founded the The Islander newspaper, which he also edited. On his return he became a principal in his own practice, still in North Finchley.

In the 1974 NHS reorganisation Tom was the only dentist with committee experience in the newly constituted Barnet LDC. As onetime chairman, secretary and editor of Barnet

Contact Point, the LDC more or less became his personal fiefdom. Tom's big scoop at the time was publicising various Item 30 discretionary fees of the now defunct Statement of Dental Remuneration which failed to amuse the DPB. Tom also served on the BDA's Representative Board and was a founder member of the British Dental Editors Forum. From 1978-1982 the office of the BDHF, now the Oral Health Foundation, was in Tom's practice. In 1998 he became an Association Life Member.

Tom retired to the Isle of Wight in 1998, where he was able to indulge his passion for gardening. He first married Carol Kirk and then Elizabeth Elliot (BDHF Executive Director at the time). His late years were spent in sheltered housing.

Tom's life was not only directed to those he cared for but also to his colleagues.

Edgar Gordon

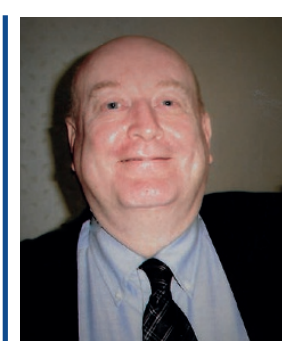

\section{Clive Holtham} Harris 1953-2018

Clive was born and educated in Birmingham before studying dentistry at Bristol Dental School. Whilst in Bristol he met his future wife, Cheryl, and on qualifying in 1975 he moved back to Birmingham, working in surgeries before eventually becoming an associate to Harold Norden who was a very active member of the Birmingham Local Dental Committee and so Clive was encouraged to join.

Clive and Cheryl were blessed with two daughters, Emma and Sarah, and subsequently a son in-law, Graham and two lovely grandsons, Harry and Findlay.

In the mid-1980s younger members of the profession became disillusioned with the effectiveness of the LDC, as it seemed to be dominated by older practitioners and a coup took place at elections, deposing the old committee; sadly, this included Clive.

But Clive became even more determined to get back, as someone committed to fighting the causes of local colleagues, and was subsequently re-elected, becoming Chair of the LDC during its most important era of 2004-08 during the introduction of the 2006 NHS contract, when under his leadership the LDC became significantly prominent in opposing its introduction.

Clive chaired the biggest ever gathering of West Midlands Dentists in November 2005 which was reported on the Midlands Evening News. It was a meeting that will live long in the memories of those that attended. Under his chairing, there were meetings with MPs, adverts in the local press opposing the contract, and a live interview to the local radio station handing in his signed, in dispute contract, at the last opportunity to the PCT.

Clive proposed a pivotal motion at the Annual Conference of LDCs in 2005 calling for unified opposition, unfortunately the motion failed. Clive went on to national representation at the GDPC and as a trusted member of the Guild. Sadly, as his health deteriorated his attendance at the meetings became fewer but he continued to take his responsibilities seriously until just a few short months ago, when he stood down at the end of his period of office which extended from 2010-18.

I and many others were inspired by his commitment to work for his colleagues, and I know he was immensely proud of the legacy he left locally and nationally on dental politics, as evidenced by the large numbers of colleagues who attended from far and wide his recent funeral.

But Clive was also a talented clinician looking after many families in the very area of Birmingham he had grown up in himself. He only retired last Christmas.

Clive sadly passed away after failing to recover from emergency surgery.

Eddie Crouch 